\title{
DINAMIKA KEDUDUKAN TAP MPR DI DALAM HIERARKI PERATURAN PERUNDANG-UNDANGAN
}

\author{
Martha Riananda \\ Fakultas Hukum, Universitas Lampung \\ Email: Martha.rianand@fh.unila.ac.id
}

\begin{abstract}
People's Consultative Assembly (MPR) decree dynamics position in the hierarchy of legislation and as the legislation arising drowned in accordance political developments and laws and regulations governing the order of legislation.
\end{abstract}

Keywords: Position, People's Consultative Assembly (MPR) and the hierarchy of legislation

abstrak

Dinamika kedudukan ketetapan MPR dalam hierarki peraturan perundangundangan dan sebagai peraturan perundang-undangan timbul tenggelam sesuai perkembangan politik dan peraturan perundang-undangan yang mengatur tentang tata urutan peraturan perundang-undangan.

Kata kunci: Kedudukan, Tap MPR dan Hierarki Peraturan Perundangundangan

\section{A. Pendahuluan}

Pengaturan tentang hierarki perundang-undangan di Indonesia dapat ditemukan dalam empat peraturan, yaitu:

1. Ketetapan MPRS Nomor XX Tahun 1966 tentang Memorandum DPRGR Mengenai Sumber Tertib Hukum Republik Indonesia dan Tata Urutan Peraturan Perundangan Republik Indonesia;

2. Ketetapan MPR Nomor III Tahun 2000 tentang Sumber Hukum dan Tata Urutan Peraturan Perundang-Undangan;

3. Undang-Undang Nomor 10 Tahun 2004 tentang Pembentukan Peraturan Perundang-Undangan; dan

4. Undang-Undang Nomor 12 Tahun 2011 tentang Pembentukan Peraturan Perundang-Undangan.

Substansi keempat peraturan tersebut mengatur secara berbeda atas jenis-jenis peraturan perundang-undangan yang termasuk ke dalam hierarki peraturan perundang-undangan. Salah satu perbedaan paling mendasar pada keempat peraturan di atas yaitu mengenai keberadaan Ketetapan MPR (Tap 
MPR) dalam hierarki peraturan perundang-undangan. Keberadaan produk kebijakan politik dan kebijakan hukum lembaga permusyawaratan rakyat tersebut disebutkan dalam hierarki sebagaimana diatur dalam Tap MPRS Nomor XX Tahun 1966 dan Tap MPR Nomor III Tahun 2000, namun tidak demikian pada Undang-Undang Nomor 10 Tahun 2004 tentang Pembentukan Peraturan Perundang-Undangan (UU No. 10 Tahun 2004). Pasal 7 ayat (1) UU No. 10 Tahun 2004 'mengeluarkan' Tap MPR dari jenis dan hierarki peraturan perundang-undangan yang ada dalam hierarki. Hal ini dapat dipahami sejalan dengan semangat zaman yang dapat dirasakan pada awal masa reformasi, yang mengarah pada penghilangan wewenang MPR sebagai lembaga tertinggi menjadi lembaga tinggi yang sejajar dengan lembaga-lembaga negara utama lainnya.

Perkembangan undang-undang tentang pembentukan peraturan perundang-undangan selanjutnya menciptakan kondisi yang berbeda, Undang-Undang Nomor 12 Tahun 2011 sebagai pengganti Undang-Undang Nomor 10 Tahun 2004 memasukan kembali Tap MPR ke dalam jenis-jenis peraturan perundang-undangan yang ada pada hierarki sebagaimana diatur dalam Pasal 7 ayat (1), yaitu bahwa jenis dan hierarki peraturan perundangundangan terdiri atas:

1. Undang-Undang Dasar Negara Republik Indonesia Tahun 1945;

2. Ketetapan Majelis Permusyawaratan Rakyat;

3. Undang-Undang/Peraturan Pemerintah Pengganti Undang-Undang;

4. Peraturan Pemerintah;

5. Peraturan Presiden;

6. Peraturan Daerah Provinsi; dan

7. Peraturan Daerah Kabupaten/Kota.

Dimasukkannya kembali $^{1}$ Tap MPR dalam hierarki peraturan perundang-undangan menimbulkan berbagai pertanyaan. Masuknya Tap MPR dalam hierarki peraturan perundang-undangan memiliki implikasi dalam sistem hukum positif di Indonesia karena peraturan perundangundangan di bawah Tap MPR tidak boleh bertentangan dengan Tap MPR sedangkan dalam UUD 1945 sudah ada sunset clausul mengenai Tap MPR. Peletakannya langsung di bawah UUD 1945 mengharuskan peraturan perundang-undangan di bawahnya termasuk undang-undang memperhatikan Tap MPR sebagai sumber muatan. ${ }^{2}$

Aspek yang merupakan indikator kedudukan Tap MPR meliputi aspek tata urutan, materi muatan dan kekuatan mengikat. Ketiga aspek tersebut

\footnotetext{
${ }^{1}$ Seperti diatur dalam Tap MPRS Nomor XX Tahun 1966 dan Tap MPR Nomor III Tahun 2000.

2 Berdasarkan Stufenbau Theorie yang dikemukakan Hans Kelsen, bahwa norma hukum itu berjenjang dalam suatu tata susunan hierarki. Peraturan yang rendah bersumber dari dan tidak boleh bertentangan dengan peraturan yang lebih tinggi.
} 
tidak dapat dilepaskan dari politik hukum sistem hukum positif Indonesia yang mengatur secara ketat mengenai tata urutan peraturan perundangundangan. Oleh karena itu, kedudukan Tap MPR di dalam hierarki peraturan perundang-undangan merupakan hal yang menarik untuk dikaji karena memiliki implikasi dalam kehidupan bernegara.

\section{B. Pembahasan}

1. Kedudukan Ketetapan MPR/S Setelah Keluarnya Ketetapan MPRS No. XX/MPRS/1966 tentang Memorandum DPR-GR Mengenai Sumber Tertib Hukum Republik Indonesia dan Tata Urutan Peraturan Perundangan Republik Indonesia

Tap MPR mulai dikenal sejak tahun 1960 yaitu sejak MPRS pertama kali bersidang dan membuat keputusan-keputusan. Praktek ini berjalan dan diteruskan oleh MPR. Karena telah berjalan cukup lama dan diterima sebagai bagian dari praktek ketatanegaraan di Indonesia, maka bentuk Tap MPR dapat dipandang sebagai salah satu peraturan perundang-undangan di Indonesia. Dalam ketentuan mengenai Peraturan Tata Tertib MPR, disebutkan bahwa Ketetapan MPR bersifat mengikat ke dalam dan ke luar MPR. Sedangkan putusan MPR yang semata-mata mengikat ke dalam disebut Keputusan MPR. ${ }^{3}$

Keberadaan Tap MPR didasarkan pada praktek ketatanegaraan atau konvensi, dalam hal ini Dicey membedakan antara kaidah hukum dan konvensi atas dasar kekuatan memaksa. Kaidah hukum dapat dipaksakan melalui proses pengadilan, sedangkan konvensi tidak. Ketaatan terhadap konvensi semata-mata karena dorongan etik. ${ }^{4}$ Konvensi ketatanegaraan sebagai sumber hukum sangat penting artinya dalam melengkapi atau mendinamisasikan kaidah-kaidah hukum dibawahnya. Apalagi muatan UUD 1945 sebelum perubahan sangat terbatas. Ketetapan MPR/S telah berkembang sebagai konvensi dan "dikukuhkan" dalam Tap No. XX/MPRS/1966 sebagai salah satu jenis peraturan perundang-undangan dalam hierarki hukum Indonesia, konvensi dan sistematisasi ini dikukuhkan dalam Tap No. VI/MPR/1973 jo. Tap No. III/MPR/1978 dan menjadi kerangka utama untuk memahami konstitusi, bahkan hukum tata negara, sejak 1960. Hal ini berlangsung sampai terbitnya Tap MPR No.

\footnotetext{
${ }^{3}$ Riri Nazriyah,MPR RI Kajian Terhadap Produk Hukum dan Prospek di Masa Dapan, (Yogyakarta: FH UII Press, 2007), hlm. 173

${ }^{4}$ Parlin M. Mangunsong, Konvensi Ketatanegaraan Sebagai Salah Satu Sarana Perubahan Undang-Undang Dasar, (Bandung: Alumni, 1992), hlm. 43 seperti dikutip olehRiri Nazriyah, MPR RI Kajian terhadap Produk Hukum dan Prospek di Masa Depan, (Yogyakarta: FH UII Press, 2007), hlm. 282
} 
III/MPR/2000 tentang Sumber Hukum dan Tata Urutan Peraturan Perundang-Undangan. ${ }^{5}$

Pada Ketetapan MPRS No. XX/MPRS/1966 menyatakan bahwa Ketetapan MPR adalah salah satu bentuk peraturan perundang-undangan yang tata urutannya berada di bawah UUD $1945 .{ }^{6}$ Dalam praktek pembuatan ketetapan oleh MPR/S, tidak semua ketetapan MPR/S mempunyai sifat atau ciri sebagai peraturan perundangan: a) umum; b) berisikan peraturan; dan c) tidak individual/konkret. Dari segi substansi, terdapat Tap MPR yang bersifat konkret/individual yang menimbulkan akibat hukum secara khusus atau bersifat konstitutif. Di samping terdapat Tap MPR yang bersifat pengaturan dan oleh karenanya dapat digolongkan sebagai sebuah peraturan perundangan dan Tap MPR yang bersifat konkret/individual yang konstitutif, terdapat juga ragam Tap MPR lain yang tidak termasuk dalam kedua macam tersebut. $^{7}$

Ragam itu adalah Tap MPR yang substansinya merupakan sebuah pernyataan keinginan atau pernyataan kehendak, komitmen, atau deklarasi, atau perintah dari MPR kepada lembaga pembuat undang-undang. Adanya keberagaman sifat dari substansi Tap MPR sebagaimana tersebut di atas sebagai akibat dari ketentuan Pasal 1 ayat (2) UUD 1945 sebelum perubahan yang menyatakan bahwa MPR adalah pelaksana kedaulatan rakyat sepenuhnya. Dengan statusnya yang demikian, MPR berhak untuk membuat berbagai macam putusan apapun dan ketetapan yang bersifat apapun yang

\footnotetext{
${ }^{5}$ Ibid, hlm. 283

${ }^{6}$ Pada Bab II Huruf A Ketetapan MPR No.XX/MPRS/1966, diatur mengenai Tata Urutan Peraturan Perundangan Republik Indonesia, yaitu:

1.bentuk-bentuk Peraturan Perundangan Republik Indonesia menurut Undang-Undang Dasar 1945 ialah sebagai berikut:

a. Undang-Undang Dasar Republik Indonesia 1945;

b.Ketetapan MPR;

c. Undang-undang Peraturan Pemerintah Pengganti Undang-undang;

d.Peraturan Pemerintah;

e. Keputusan Presiden;

f. Peraturan-peraturan Pelaksanaan lainnya seperti :

1) Peraturan Menteri;

2) Instruksi Menteri;

3) dan lain-lainnya.

2.sesuai dengan sistem konstitusi seperti yang dijelaskan dalam Penjelasan autentik Undang-Undang Dasar 1945, bentuk peraturan perundangan yang tertinggi, yang menjadi dasar dan sumber bagi semua peraturan-perundangan bawahan dalam Negara; dan

3.sesuai pula dengan prinsip Negara hukum, maka setiap peraturan perundangan harus berdasar dan bersumber dengan tegas pada peraturan perundangan yang berlaku, yang lebih tinggi tingkatnya.

${ }^{7}$ Harjono, Konstitusi Sebagai Rumah Bangsa, (Jakarta: sekretariat jenderal dan Kepaniteraan Mahkamah Konstitusi, 2008), hlm. 512
} 
dituangkan dalam bentuk Tap MPR/S. ${ }^{8}$ Penjelasan UUD 1945 memberi arti bahwa: Majelis ialah penyelenggara negara yang tertinggi. Majelis ini dianggap sebagai penjelmaan rakyat yang memegang kedaulatan negara. ${ }^{9}$ Selanjutnya penjelasan Pasal 3 menyebutkan: oleh karena MPR memegang kedaulatan negara maka kekuasaannya tidak terbatas. ${ }^{10}$

Dalam prakteknya, sebutan bagi Lembaga Tertinggi Negara dengan kekuasaan tidak terbatas digunakan sebagai alat antara lain memperbesar kekuasaan presiden di luar ketentuan UUD 1945, seperti Tap MPR yang memberi kekuasaan tidak terbatas kepada presiden demi pembangunan. ${ }^{11}$

Disamping itu, kekuasan tidak terbatas telah dipergunakan untuk membuat berbagai ketetapan di luar wewenang MPR diluar materi muatan dan tata cara yang ditentukan dalam UUD 1945. Hal yang sama terjadi pada masa orde lama, seperti pengangkatan Presiden Soekarno menjadi presiden seumur hidup. ${ }^{12}$ Praktek ketatanegaraan ini merupakan pelanggaran terhadap UUD 1945 dan semuanya dianggap bersumber dari penyalahgunaan arti MPR sebagai penyelenggara negara tertinggi yang memegang kedaulatan negara yang disertai kekuasaan tidak terbatas. ${ }^{13}$

Penempatan Tap MPR dalam urutan kedua dalam Tata Urutan Peraturan Perundangan menurut Ketetapan MPRS No. XX/MPRS/1966 dan dengan mempertimbangkan praktek bahwa Tap MPR mempunyai berbagai macam sifat sebagaimana disebut di atas menyebabkan Tap MPR memiliki kedudukan yang sangat spesifik dalam sebuah undang-undang yang urutan letaknya berada dibawah Tap MPR. Maksud disusunnya tata urutan peraturan perundangan adalah agar suatu bentuk peraturan perundangan jelas letak urutannya dan dengan demikian pula jelas sumber dan dasar hukum bagi sebuah peraturan perundang-undangan tersebut, yaitu peraturan perundangan yang urutannya berada di atasnya. Dalam penyusunan undangundang, sebagai peraturan perundangan di bawah Tap MPR, fungsi Tap MPR dapat menjadi sumber hukum materiil dan sumber hukum formil. Sebagai sumber hukum materiil dari sebuah undang-undang, sebuah Tap MPR perlu untuk dimasukkan ke dalam konsideran "menimbang" sebuah undang-undang. ${ }^{14}$

\footnotetext{
${ }^{8}$ Ibid, hlm. 512-513

${ }^{9}$ Penjelasan Pasal 1

${ }^{10}$ Penjelasan Pasal 3: oleh karena MPR memegang kedaulatan negara, maka kekuasannya tidak terbatas, mengingat dinamik masyarakat, sekali dalam lima tahun Majelis memperhatikan segala yang terjadi dan segala aliran-aliran pada waktu itu dan menentukan haluan-haluan apa dan hendaknya dipakai untuk dikemudian hari.

${ }^{11}$ Tap MPR No. V Tahun 1998.

${ }^{12}$ Tap MPRS No. III/MPRS/1963.

${ }^{13}$ Bagir Manan, DPR, DPD, dan MPR dalam UUD 1945 Baru, (Yogyakarta: FH UII PRESS, 2003), hlm. 78.

${ }^{14}$ Harjono, Op.cit hlm. 513.
} 
Ketetapan MPR yang berisikan pernyataan keinginan, kehendak, perintah, komitmen, atau deklarasi dapat dijadikan sumber materiil dari sebuah undang-undang. Sebagai sumber hukum formal sebuah undangundang, Tap MPR dimasukkan dalam konsideran "mengingat" dalam sebuah undang-undang. Tap MPR yang berisi aturan yang bersifat umum yang oleh karenanya termasuk dalam peraturan perundangan, atau sebuah keputusan konkret yang bersifat konstitutif yang berkaitan dengan substansi undangundang yang dibuat, perlu dicantumkan dalam konsideran "mengingat" undang-undang yang bersangkutan. ${ }^{15}$

Menurut ketentuan pasal 3 juncto Pasal 37 UUD 1945 yang asli, salah satu kewenangan MPR adalah menetapkan Garis-Garis Besar Haluan Negara. Mengapa MPR diberi kewenangan menetapkan Garis-Garis Besar Haluan Negara? Selain untuk memberi pedoman kerja dan panduan penyusunan program kerja bagi presiden dalam melaksanakan tugasnya, Garis-Garis Besar Haluan Negara itu diperlukan karena pedoman atau haluan-haluan kebijakan bernegara yang ditentukan dalam UUD 1945 sangat atau bahkan terlalu ringkas dan sederhana. Oleh karena itu, di samping haluan-haluan yang telah ditentukan dalam UUD 1945, maka diperlukan haluan-haluan negara yang lebih jelas di luar UUD $1945 .{ }^{16}$

Dengan pertimbangan yang demikian, maka haluan-haluan negara yang dimaksud perlu dituangkan dalam bentuk ketetapan-ketetapan yang mengatur dengan daya ikat tinggi yang efektif. Karena kedudukan MPR sendiri lebih tinggi daripada presiden dan DPR, maka dengan sendirinya kedudukan Tap MPR/S dianggap lebih tinggi daripada undang-undang. Sesungguhnya, ketetapan-ketetapan MPR/S yang bersifat mengatur itu juga mempunyai kedudukan sebagai hukum konstitusi, karena dibuat dan ditetapkan oleh lembaga yang sama dengan yang menetapkan UUD. Karena itu, sebenarnya adanya Tap MPR/S sebagai produk hukum yang mengatur (regeling) merupakan bentuk penafsiran MPR atas UUD 1945 yang dikenal sangat ringkas. Ketetapan yang berisi penafsiran dan elaborasi normatif itu diperlukan untuk melengkapi haluan-haluan negara yang terdapat dalam konstitusi tertulis yang belum lengkap itu. Dengan perkataan lain, Tap MPR/S itu juga mempunyai nilai konstitusi atau sebagai bentuk penafsiran atau bahkan merupakan perubahan UUD dalam bentuk yang tidak resmi menurut ketentuan Pasal 37 UUD 1945. Hanya saja, karena prosedur pembahasan dan pengambilan dalam proses pembentukan Tap MPR/S itu memang berbeda dari penyusunan atau perubahan UUD menurut ketentuan Pasal 37 UUD 1945, maka kedudukan keduanya dianggap tidak sederajat. UUD sebagai hukum tertinggi tetap mempunyai kedudukan yang lebih tinggi

\footnotetext{
${ }^{15}$ Harjono, op.cit hlm. 514.

${ }^{16}$ Jimly asshiddiqie, Perihal Undang-undang, (Jakarta: Raja Grafindo Persada, 2011), hlm. 33.
} 
daripada Tap MPR/S lainnya. Itu sebabnya, Ketetapan MPRS No. XX/MPRS/1966 menentukan hierarki Tap MPR/S itu sebagai peraturan di bawah UUD, tetapi di atas UU. ${ }^{17}$

\section{Kedudukan Ketetapan MPR Setelah Keluarnya Tap MPR Nomor III Tahun 2000 Tentang Sumber Hukum dan Tata Urutan Peraturan Perundang-Undangan Ketetapan Majelis Permusyawaratan Rakyat Republik Indonesia}

Sistemisasi tentang sumber dan hierarki tata urutan peraturan perundang-undangan selanjutnya dilakukan pada Sidang Umum MPR Tahun 2000 yang menetapkan Tap MPR Nomor III Tahun 2000 tentang Sumber Hukum dan Tata Urutan Peraturan Perundang-Undangan. Meskipun sistemisasi ini serupa dengan dengan Tap MPRS No. XX/MPRS/1966, tetapi di antara keduanya terdapat perbedaan mencolok yang bersifat problematik.

Tap MPR Nomor III Tahun 2000 yang menentukan hierarki peraturan perundang-undangan pada Pasal 2, yaitu Tata Urutan Peraturan PerundangUndangan merupakan pedoman dalam pembuatan aturan hukum di bawahnya. Tata Urutan Peraturan Perundang-Undangan Republik Indonesia adalah:

a. Undang-Undang Dasar 1945;

b. Ketetapan Majelis Permusyawaratan Rakyat Republik Indonesia;

c. Undang-Undang;

d. Peraturan Pemerintah Pengganti Undang-Undang (Perpu);

e. Peraturan Pemerintah;

f. Keputusan Presiden yang Bersifat Mengatur; dan

g. Peraturan Daerah.

Seperti halnya materi muatan Tap MPR/S pada Tap No. XX/MPRS/1960, materi muatan Tap MPR/S pada masa ini juga masih sangat luas. Belum ada pembatasan terhadap materi muatan yang dapat termuat dalam Tap MPR/S.

Hingga sampai akhirnya, MPR hasil Pemilu 1999 yang diselenggarakan dengan cukup demokratis, menindaklanjuti tuntutan masyarakat yang menghendaki perubahan UUD 1945 dengan melakukan satu rangkaian perubahan konstitusi dalam empat tahapan yang berkesinambungan, sejak Sidang Umum MPR Tahun 1999 sampai dengan Sidang Tahunan MPR Tahun 2002. ${ }^{18}$ Perubahan UUD 1945 ini membawa implikasi terhadap kedudukan, tugas, dan wewenang MPR.

\footnotetext{
${ }^{17}$ Ibid, hlm. 34.

${ }^{18}$ MPR RI 2004-2009 Aktifitas dan Dinamika, (Jakarta: Sekretariat Jenderal MPR RI, 2009), hlm. 142.
} 
Berubahnya kedudukan MPR juga berimplikasi kepada tugas dan wewenang MPR. MPR tidak lagi mempunyai wewenang dan tugas yang sama. Perubahan tugas dan wewenang ini, khususnya yang berkenaan dengan hilangnya tugas dan wewenang MPR untuk menetapkan Garis-Garis Besar dari pada Haluan Negara, selanjutnya berimplikasi pada materi dan status hukum Tap MPR/S yang telah dihasilkan sejak tahun 1960 sampai tahun 2002. Oleh sebab itu, dalam Pasal I Aturan Tambahan UUD 1945, MPR ditugasi untuk melakukan peninjauan kembali terhadap materi dan status hukum Tap MPR/S untuk diambil putusan pada Sidang MPR Tahun 2003. ${ }^{19}$

Setelah perubahan UUD 1945 dilakukan secara lengkap, yaitu dengan adanya perubahan keempat tahun 2002, MPR pada Tahun 2003 menetapkan Tap MPR pada Sidang Tahunan MPR Tahun 2003, MPR menetapkan Tap MPR No. I/MPR/2003 tentang Peninjauan terhadap Materi dan Status Hukum Ketetapan MPRS dan Ketetapan MPR RI Tahun 1960 sampai dengan Tahun 2002. Ketetapan tersebut terbit disebabkan adanya perubahan yang mendasar dalam sistem ketatanegaraan oleh adanya perubahan sampai dengan IV UUD 1945. Dengan demikian, dapat dikatakan bahwa fungsi dari Tap MPR No. I/MPR/2003 adalah sebagai aturan peralihan. ${ }^{20}$

Dasar hukum pembentukan Ketetapan MPR RI Nomor I/MPR/2003 yang utama adalah Pasal I Aturan Tambahan dan Pasal I dan Pasal II Aturan Peralihan Undang-Undang Dasar Negara Republik Indonesia Tahun 1945 yang ditetapkan oleh MPR dalam Sidang Tahunan MPR pada bulan Agustus 2002.

Tujuan pembentukan Ketetapan MPR RI Nomor I/MPR/2003 tentang Peninjauan terhadap Materi dan Status Hukum Ketetapan Majelis Permusyawaratan Rakyat Sementara dan Ketetapan Majelis Permusyawaratan Rakyat Republik Indonesia Tahun 1960 sampai dengan Tahun 2002 adalah meninjau dan menentukan hal-hal yang berhubungan dengan materi dan status hukum setiap Ketetapan MPRS dan Ketetapan MPR yang masih ada saat ini, serta menetapkan bagaimana keberadaan (eksistensi) dari Ketetapan MPRS dan Ketetapan MPR tersebut untuk saat ini dan masa yang akan datang. Peninjauan tersebut juga dilakukan untuk menghindari adanya ketidakpastian hukum yang akan terjadi dengan berlakunya seluruh sistem pemerintahan negara berdasarkan UndangUndang Dasar Negara Republik Indonesia Tahun 1945 setelah selesainya seluruh perubahan yang dilakukan oleh MPR. ${ }^{21}$

Perubahan kewenangan MPR dalam hal pembentukan Ketetapan MPR yang berlaku ke luar membawa pula akibat perubahan pada kedudukan dan

\footnotetext{
${ }^{19}$ Ibid, hlm. 143.

${ }^{20}$ Harjono, Op.cit, hlm. 514.

${ }^{21}$ Panduan, Ibid. hlm 209.
} 
status hukum Ketetapan MPRS dan Ketetapan MPR dalam tata susunan (hierarki) Peraturan Perundang-Undangan Republik Indonesia. ${ }^{22}$

Dalam masa transisi berlakunya Undang-Undang Dasar Negara Republik Indonesia Tahun 1945 (sebelum perubahan) ke masa berlakunya Undang-Undang Dasar Negara Republik Indonesia Tahun 1945 (setelah perubahan), dan untuk melakukan "penyesuaian" terhadap segala perubahan yang terjadi, dalam Sidang Tahunan MPR Tahun 2003, sebagaimana tugas yang diamanatkan oleh Pasal I Aturan Tambahan, Pasal I dan Pasal II Aturan Peralihan Undang-Undang Dasar Negara Republik Indonesia Tahun 1945 maka MPR membentuk sebuah ketetapan yaitu Ketetapan MPR RI Nomor I/MPR/2003 yang berisi peninjauan terhadap materi dan status hukum Ketetapan-Ketetapan MPRS dan MPR dari tahun 1960 sampai dengan tahun 2002. ${ }^{23}$

Perubahan Keempat Undang-Undang Dasar Negara Republik Indonesia Tahun 1945 telah menegaskan bahwa perubahan Undang-Undang Dasar Negara Republik Indonesia Tahun 1945 mulai berlaku pada tanggal ditetapkan, yaitu tanggal 10 Agustus 2002. Namun, pada saat itu masih terdapat sejumlah Ketetapan MPRS dan Ketetapan MPR yang secara hukum masih berlaku. Ketetapan MPRS dan Ketetapan MPR yang secara hukum masih berlaku tersebut, kadang-kadang secara nyata tetap menjadi pedoman bagi masyarakat atau pun bagi pejabat dalam membentuk berbagai peraturan perundang-undangan dalam rangka menyelenggarakan pemerintahan negara. Selain itu, terdapat juga Ketetapan MPRS dan Ketetapan MPR yang masih diinginkan oleh masyarakat luas untuk dipertahankan eksistensinya. ${ }^{24}$

Karena selama masa tahun 1960 sampai dengan tahun 2002 masih terdapat sebanyak 139 Ketetapan MPRS dan Ketetapan MPR yang secara hukum masih berlaku. MPR melalui Panitia Ad Hoc II melakukan berbagai pengkajian dan analisis terhadap seluruh Ketetapan MPRS dan Ketetapan MPR tersebut. Kajian dan analisis tersebut kemudian ditetapkan dalam Ketetapan MPR RI Nomor I/MPR/2003 yang menempatkan seluruh Ketetapan MPRS dan Ketetapan MPR tersebut sesuai dengan materi dan status hukumnya.

Peninjauan terhadap seluruh Ketetapan MPRS dan Ketetapan MPR dilakukan dengan pengkajian dan analisis tentang materi atau substansi yang dirumuskan dalam setiap Ketetapan MPRS dan Ketetapan MPR yang dibentuk antara tahun 1960 sampai dengan tahun 2002, kemudian memisahkannya dalam kelompok-kelompok yang mempunyai kesamaan materi. Sementara itu, peninjauan terhadap status hukum Ketetapan MPRS dan Ketetapan MPR dilakukan dengan melakukan pengkajian dan analisis

\footnotetext{
${ }^{22}$ Ibid.

${ }^{23}$ Ibid.

${ }^{24}$ Ibid. hlm. 207.
} 
terhadap substansi yang terdapat dalam setiap Ketetapan MPRS dan Ketetapan MPR tersebut, kemudian menentukannya dalam kelompokkelompok yang mempunyai kesamaan status hukum untuk mendapatkan kepastian tentang berbagai sifat norma yang terkandung di dalamnya. ${ }^{25}$

Ditinjau dari sudut materi atau substansi norma hukum yang terdapat dalam Ketetapan MPRS dan Ketetapan MPR dapat dibedakan sebagai berikut: ${ }^{26}$

a. dari segi alamat yang dituju/diatur (adressat norm) dapat dibedakan antara yang bersifat individual dan yang bersifat umum;

b. dari segi hal yang diatur dapat dibedakan antara yang bersifat konkret dan abstrak; dan

c. dari segi keberlakuannya dapat dibedakan antara yang bersifat final/sekali-selesai (einmalig) dan yang bersifat terus menerus (tetap berlaku dengan ketentuan).

Berdasarkan peninjauan yang dilakukan, tidak semua Ketetapan MPRS dan Ketetapan MPR memiliki norma hukum yang sejenis untuk keseluruhan pasalnya dan juga sifat yang dimiliki ketetapan tersebut. Dalam suatu Ketetapan MPRS dan Ketetapan MPR tidak jarang pasal-pasalnya merupakan campuran dari norma hukum yang bersifat pengaturan (regeling) dan norma hukum yang bersifat penetapan (beschiking). ${ }^{27}$

Dengan demikian pengelompokan Ketetapan MPRS dan Ketetapan MPR yang dilakukan peninjauan dari segi keberlakuannya juga mengandung makna dibatasi di samping yang bersifat final/sekali-selesai (einmalig) dan yang bersifat terus menerus (tetap berlaku dengan ketentuan). ${ }^{28}$

Pengelompokan yang bersifat dibatasi adalah jika substansi dari Ketetapan MPRS dan Ketetapan MPR tersebut: ${ }^{29}$

a. telah berakhir masa berlakunya dan/atau materinya sudah diatur dalam Undang-Undang Dasar Negara Republik Indonesia Tahun 1945;

b. berlaku sampai dengan terbentuknya pemerintahan hasil pemilihan umum tahun 2004;

c. tetap berlaku sampai dengan terbentuknya undang-undang; dan

d. masih berlaku sampai dengan ditetapkannya Peraturan Tata Tertib yang baru oleh Majelis Permusyawaratan Rakyat Republik Indonesia hasil pemilihan umum tahun 2004.

Dengan ditetapkannya Ketetapan MPR tersebut, seluruh Ketetapan MPRS dan Ketetapan MPR yang berjumlah 139 dikelompokkan ke dalam 6

\footnotetext{
${ }^{25}$ Ibid. hlm. 210.

${ }^{26}$ Ibid. hlm. 211.

${ }^{27}$ Ibid. hlm. 211.

${ }^{28}$ Ibid.

${ }^{29}$ Ibid, hlm. 212.
} 
pasal (kategori) sesuai dengan materi dan status hukumnya. Substansi Ketetapan MPR tersebut adalah:

a. Kategori I: TAP MPRS/TAP MPR yang dicabut dan dinyatakan tidak berlaku (8 Ketetapan);

b. Kategori II: TAP MPRS/TAP MPR yang dinyatakan tetap berlaku dengan ketentuan (3 Ketetapan);

c. Kategori III: TAP MPRS/TAP MPR yang dinyatakan tetap berlaku sampai dengan terbentuknya Pemerintahan Hasil Pemilu 2004 (8 Ketetapan);

d. Kategori IV: TAP MPRS/TAP MPR yang dinyatakan tetap berlaku sampai dengan terbentuknya Undang-Undang (11 Ketetapan);

e. Kategori V: TAP MPRS/TAP MPR yang dinyatakan masih berlaku sampai dengan ditetapkannya Peraturan Tata Tertib Baru oleh MPR Hasil Pemilu 2004 (5 Ketetapan); dan

f. Kategori VI: TAP MPRS/TAP MPR yang dinyatakan tidak perlu dilakukan tindakan hukum lebih lanjut, baik karena bersifat final (einmalig), telah dicabut, maupun telah selesai dilaksanakan (104 Ketetapan).

Dengan begitu, status hukum dari keseluruhan Ketetapan MPRS dan Ketetapan MPR selama kurun waktu tahun 1960 sampai dengan tahun 2002 menjadi jelas dan sampai dengan tahun 2012 berarti Tap MPR/S yang masih berlaku ada tujuh, yaitu satu Tap MPRS dan enam Tap MPR.

Berdasarkan hasil peninjauan Tap MPR/S tersebut diatas dan wewenang yang dimiliki oleh MPR setelah adanya Perubahan UUD 1945, MPR tidak lagi berwenang menerbitkan Tap MPR yang bersifat mengatur (regeling) oleh sebab itu, Tap MPR tidak dapat lagi dijadikan sebagai sumber hukum dan harus dikeluarkan dari hierarki peraturan perundangundangan. ${ }^{30}$

\section{Kedudukan Ketetapan MPR Setelah Keluarnya Undang-Undang Nomor 10 Tahun 2004 tentang Pembentukan Peraturan Perundang- Undangan}

Setelah terbitnya TAP MPR No I/MPR/2003 tentang Peninjauan terhadap Materi dan Status Hukum Ketetapan MPRS/MPR RI Tahun 19602002, Ketetapan MPR berada di simpang jalan. Di satu pihak Tap MPR/S yang masih berlaku ada tujuh. Ketujuh Tap tersebut adalah Ketetapan Majelis Permusyawaratan Rakyat Sementara Republik Indonesia Nomor XXV/MPRS/1966 tentang Pembubaran Partai Komunis Indonesia, Pernyataan Sebagai Organisasi Terlarang di Seluruh Wilayah Negara Republik Indonesia bagi Partai Komunis Indonesia dan Larangan Setiap

\footnotetext{
${ }^{30}$ Riri nazriyah, MPR RI... Op.Cit. Hlm. 297.
} 
Kegiatan untuk Menyebarkan atau Mengembangkan Paham atau Ajaran Komunis/Marxisme-Leninisme; Ketetapan MPR RI Nomor XVI/MPR/1998 tentang Politik Ekonomi dalam Rangka Demokrasi Ekonomi; Ketetapan MPR RI Nomor XI/MPR/1998 tentang Penyelenggara Negara yang Bersih dan Bebas KKN; Ketetapan MPR Nomor VI/MPR/2001 tentang Etika Kehidupan Berbangsa; Ketetapan MPR Nomor VII/MPR/2001 tentang Visi Indonesia Masa Depan; Ketetapan MPR Nomor VIII/MPR/2001 tentang Rekomendasi Arah Kebijakan Pemberantasan dan Pencegahan KKN; dan Ketetapan Majelis Permusyawaratan Rakyat Republik Indonesia Nomor IX/MPR/2001 tentang Pembaruan Agraria dan Pengelolaan Sumber Daya Alam sampai terlaksananya seluruh ketentuan dalam Ketetapan tersebut.

Ketujuh Ketetapan yang masih berlaku itu masih memiliki daya laku (validity) dan daya guna (efficacy), tetapi pada sisi yang lain setelah keluarnya UU No. 10 Tahun 2004 tentang Pembentukan Peraturan Perundang-Undangan tidak lagi menempatkan TAP MPR dalam jenis dan hierarki Peraturan Perundang-Undangan. Memang benar pada Pasal 7 UU ini dinyatakan bahwa "Jenis Peraturan Perundang-Undangan selain sebagaimana dimaksud Ayat (1) diakui keberadaannya dan mempunyai kekuatan hukum mengikat sepanjang diperintahkan oleh Peraturan Perundang-Undangan yang lebih tinggi”, serta kemudian juga dijelaskan lagi dalam Penjelasan Pasal 7 ayat (4) Ayat (4) Jenis Peraturan PerundangUndangan selain dalam ketentuan ini, antara lain, peraturan yang dikeluarkan oleh Majelis Permusyawaratan Rakyat dan Dewan Perwakilan Rakyat, Dewan Perwakilan Daerah, Mahkamah Agung, Mahkamah Konstitusi, Badan Pemeriksa Keuangan, Bank Indonesia, Menteri, kepala badan, lembaga, atau komisi yang setingkat yang dibentuk oleh undangundang atau pemerintah atas perintah undang-undang, Dewan Perwakilan Rakyat Daerah Provinsi, Gubernur, Dewan Perwakilan Rakyat Daerah Kabupaten/Kota, Bupati/Walikota, Kepala Desa atau yang setingkat.

Berdasarkan hasil peninjauan ketetapan-ketetapan MPR/S tersebut di atas dan wewenang yang dimiliki oleh MPR setelah adanya perubahan UUD 1945, MPR tidak lagi berwenang menerbitkan Tap MPR yang bersifat mengatur. Oleh sebab itu, Tap MPR tidak lagi dijadikan sebagai sumber hukum dan harus dikeluarkan dari hierarki peraturan perundang-undangan. ${ }^{31}$ Di dalam ketentuan UU No. 10 Tahun 2004 tentang Pembentukan Peraturan Perundang-Undangan dimaksudkan untuk menggantikan fungsi dan mengadopsikan materi Ketetapan No. III/MPR/2000, bentuk-bentuk peraturan perundang-undangan itu ditentukan atas jenis dan hierarki Peraturan Perundang-Undangan adalah sebagai berikut :

a. Undang-Undang Dasar Negara Republik Indonesia Tahun 1945;

\footnotetext{
${ }^{31}$ Riri Nazriyah, Op.Cit. hlm. 297.
} 
b. Undang-Undang/Peraturan Pemerintah Pengganti Undang-Undang;

c. Peraturan Pemerintah;

d. Peraturan Presiden; dan

e. Peraturan Daerah.

Dalam ketentuan tersebut di atas, status Tap MPR sebagai salah satu bentuk peraturan perundang-undangan ditiadakan. Karena itu, MPR hasil Pemilu 2004 telah mendasarkan diri kepada UUD 1945 pasca perubahan keempat tahun 2002.

Dari uraian di atas nampak bahwa keberadaan Tap MPR/S setelah perubahan UUD 1945 masih menimbulkan persoalan, status hukumnya tidak jelas karena Tap tersebut pada kenyataannya masih dan dinyatakan masih berlaku, tetapi tidak lagi sebagai sumber hukum formal. Untuk itu, upaya menyikapi ketidakjelasan status hukum Tap MPR/S seharusnya segera dibentuk peraturan perundang-undangan guna menampung persoalanpersoalan yang berkaitan dengan masalah tersebut dan Tap MPR yang masih dinyatakan berlaku hanya dijadikan sumber hukum materiil. ${ }^{32}$

Sekarang, masalahnya adalah apakah berbagai Tap MPR/S tersebut dapat dikatakan mempunyai status hukum yang sederajat dengan undangundang atau sederajat dengan UUD? Hal ini penting untuk dipastikan karena MPR menurut UUD 1945 pasca perubahan keempat tidak lagi memiliki kewenangan untuk menilai dan membahas atau menjadikannya objek pembahasan dalam persidangan MPR. MPR tidak lagi membicarakan putusan-putusan yang pernah ia buat sendiri dimasa lalu seperti ketetapanketetapan seperti tersebut di atas. Setelah perubahan UUD 1945, MPR hanya dapat mengagendakan pembahasan mengenai salah satu dari empat kewenangan MPR. Diluar keempat agenda yang terkait kewenangan MPR, tidak dikenal adanya sidang MPR yang lain. ${ }^{33}$ Status hukum Tap MPR setelah Pemilu 2004 sangat erat kaitannya dengan materi muatan yang terkandung dalam setiap Tap tersebut. Selain itu status hukum Tap berhubungan pula dengan sifat aturan hukum yang dirumuskan di dalamnya.

Jika dipandang dari segi bentuknya dan lembaga yang berwenang menetapkannya, jelas bahwa Tap MPR/S sama sekali bukanlah UU. Ketujuh Tap MPR/S dapat dinilai lebih tinggi daripada UU dan karena itu setara dengan UUD, karena beberapa alasan. Pertama, secara historis sampai dengan pelaksanaan Sidang MPR Tahun 2003, kedudukannya memang pernah lebih tinggi daripada kedudukan UU seperti yang ditentukan oleh Tap MPR No. III/2000. Kedua, dari segi bentuknya, ketujuh Tap MPR/S itu jelas pula bukan berbentuk UU, sehingga tidak dapat disetarakan dengan UU. Ketiga, dari segi lembaga pembentuk atau lembaga negara yang

\footnotetext{
${ }^{32}$ Riri Nazriyah, Op.Cit. hlm. 315.

${ }^{33}$ Jimly Assidiqie, Perihal Undang-undang..., Op.Cit. hlm. 48.
} 
menetapkannya, jelas pula bahwa Tap MPR/S tidak ditetapkan oleh pembentuk UU, yaitu DPR bersama-sama dengan Presiden, melainkan oleh MPR dan MPRS. ${ }^{34}$

Nampak bahwa keberadaan ketujuh Tap MPR/S setelah perubahan UUD 1945 dan keluar UU No. 10 Tahun 2004 masih menimbulkan persoalan, status hukumnya tidak jelas karena ketetapan tersebut dalam kenyataannya masih ada dan dinyatakan masih berlaku, tetapi tidak lagi sebagai sumber hukum formal. Untuk itu, perlu upaya untuk mengatasi ketidakjelasan status dari ketujuh Tap MPR/S tersebut.

\section{Kedudukan Ketetapan MPR setelah Keluarnya Undang-Undang Nomor 12 Tahun 2011 tentang Pembentukan Peraturan Perundang- Undangan}

Ketidakjelasan status dari ketujuh Tap MPR/S tersebut kemudian dijawab dengan dimunculkannya kembali TAP MPR dalam Undang-Undang Nomor 12 Tahun 2011 tentang Pembentukan Peraturan PerundangUndangan. Dengan berlakunya undang-undang yang baru ini otomatis UU No. 10 Tahun 2004 dinyatakan dicabut dan tidak berlaku lagi.

TAP MPR yang dalam UU No. 10 Tahun 2004 dihapuskan dari hierarki perundang-undangan, dalam UU No. 12 Tahun 2011 dimunculkan kembali dan berada di bawah UUD 1945 seperti yang pernah diatur dalam Tap MPR No. III/MPR/2000. Implikasinya sungguh sangat besar dan signifikan. Tap MPR kembali menjadi sumber hukum formal dan material. Tap MPR harus kembali menjadi rujukan atau salah satu rujukan selain UUD 1945 bukan hanya dalam pembentukan perundang-undangan di negeri ini, melainkan juga dalam pembentukan kebijakan-kebijakan publik lainnya. DPR dan Pemerintah (Presiden) mutlak harus memperhatikan Tap-Tap MPR yang masih berlaku, bahkan merujuk kepadanya dalam pembentukan undang-undang dan peraturan perundang-undangan dibawahnya. Demikian juga dengan pembentukan Peraturan Pemerintah (PP), Peraturan Presiden (Perpres), dan Peraturan Daerah (Perda) mutlak harus mendasarkan secara formal dan material kepada Tap MPR.

Di dalam UU No. 12 Tahun 2011 tentang Pembentukan Peraturan Perundang-Undangan tidak menentukan materi muatan dari berbagai jenis peraturan tersebut, serta bagaimana kedudukan dari peraturan-peraturan tersebut dan bagaimana kedudukan dari peraturan-peraturan tersebut terhadap peraturan yang telah ditetapkan penjenjangannya dalam Pasal 7 ayat (1) UU No. 12 Tahun 2011.

\footnotetext{
${ }^{34}$ Ibid.
} 


\section{Penutup}

Saat ini UU No. 12 tahun 2011 meletakkan kembali Tap MPR/S dalam hierarki peraturan perundang-undangan. Walaupun Tap MPR yang dimaksudkan di sini adalah Tap MPR/S yang masih berlaku sebagaimana yang dimaksud dalam Pasal 2 dan Pasal 4 Tap MPR No. I/MPR/2003, yang dimaksudkan agar Tap MPR/S yang masih berlaku memiliki status hukum karena sebagian substansi Tap MPR tersebut belum tertampung di dalam peraturan perundang-undangan, tapi seharusnya Tap-Tap MPR/S tersebut harus dipandang tidak lagi sebagai sumber hukum formal tetapi sebagai sumber hukum material. Kemudian terhadap Tap MPR yang masih tersisa adalah harus ada upaya untuk menyikapinya yaitu dengan membentuk peraturan perundang-undangan guna menampung persoalan-persoalan yang berkaitan dengan masalah tersebut dan Tap MPR yang masih berlaku hanya dijadikan sumber hukum materiil. Sebenarnya, tidak ada lagi argumentasi yang dapat dijadikan alasan untuk mempertahankan dasar hukum kedudukan Tap MPR di dalam hierarki perundang-undangan. Sehingga penulis lebih setuju bila Ketetapan MPR tidak masuk ke dalam Hierarki Peraturan Perundang-undangan.

\section{Daftar Pustaka}

\section{A. Buku}

Asshiddiqie, Jimly, 2011. Perihal Undang-undang, Jakarta: Raja Grafindo Persada.

Harjono, 2008. Konstitusi Sebagai Rumah Bangsa, Jakarta: Sekretariat Jenderal dan Kepaniteraan Mahkamah Konstitusi.

Mangunsong, Parlin M., 1992. Konvensi Ketatanegaraan Sebagai Salah Satu Sarana Perubahan Undang-Undang Dasar, Bandung: Alumni.

Manan, Bagir, 2003. DPR, DPD, dan MPR dalam UUD 1945 Baru, Yogyakarta: FH UII PRESS.

MPR RI 2004-2009 Aktifitas dan Dinamika, 2009. Jakarta: Sekretariat Jenderal MPR RI.

Nazriyah, Riri, 2007. MPR RI Kajian Terhadap Produk Hukum dan Prospek di Masa Depan, Yogyakarta: FH UII Press.

\section{B. Peraturan Perundang-undangan}

UUD 1945

Ketetapan MPRS Nomor XX Tahun 1966 tentang Memorandum DPRGRMengenai Sumber Tertib Hukum Republik Indonesia dan Tata Urutan Peraturan Perundangan Republik Indonesia. 
Ketetapan MPRNomor III Tahun 2000 tentang Sumber Hukum dan Tata Urutan Peraturan Perundang-Undangan.

Undang-Undang Nomor 10 Tahun 2004 tentang Pembentukan Peraturan Perundang-undangan.

Undang-Undang Nomor 12 Tahun 2011 tentang Pembentukan Peraturan Perundang-undangan.

Ketetapan MPR RI Nomor I/MPR/2003 tentang Peninjauan Terhadap Materi dan Status Hukum Ketetapan Majelis Permusyawaratan Rakyat Sementara dan Ketetapan Majelis Permusyawaratan Rakyat Republik Indonesia Tahun 1960 sampai dengan Tahun 2002. 